\title{
The Insistence Upon Community in the Contemporary Afro-American Novel
}

Bigger thomas waits Defiantly and alone for death at the conclusion of Richard Wright's Native Son (1940). The narrator of Ralph Ellison's Invisible Man (1952) sits meditating and alone in a well-lighted cellar at the end of that novel. Kabnis sneers and stumbles alone up the stairs from another cellar on the last page of Jean Toomer's Cane (1923). Thus, the protagonists in some major Afro-American novels, like those in well-known novels by white Americans, often find themselves lighting out for the territory of life quite alone.

The isolation of the protagonists of these Afro-American novels is, according to Roger Rosenblatt, American, modern, and tragic; it results from the absence of a strong cultural tradition which would allow the individual to develop a sure sense of self. ${ }^{1}$ Rosenblatt's view of the tragedy of the black protagonist and the failure of the black community is based primarily on novels written in the first fifty years of this century, and it is vigorously challenged by Afro-American novels of the sixties and seventies. Although such recent works as Charles Wright's The Wig (1966), Nathan Heard's Howard Street (1968), Berry Beckham's My Main Mother (1969), and Toni Morrison's The Bluest Eye (1970) and Sula (1973) do describe individuals as alienated as Bigger Thomas, a range of other contemporary Afro-American novels describe a vital community with a culture which nurtures its members. Consequently, like Brer Rabbit, the protagonists of these novels choose emphatically to stay at home in the Briar Patch, for here is the secret of personal identity and survival; here, finally, is the source of life which is more significant by far than the life of the lone individual.

Richard Chase places the causes for the isolation of the individual in novels writ-

\footnotetext{
${ }^{1}$ Roger Rosenblatt, Black Fiction (Cambridge, Mass.: Harvard University Press, 1974), pp. 6-11. He elaborates upon the consequent desperate and perverse behavior of characters in black fiction: "[They] behave savagely in order to be considered civilized, rise in order to fall, sin in order to gain salvation, are rewarded for virtue by damnation, assert their presence by disappearing, are old when they are young, act as children in old age, are emancipated so they may be enslaved, see when they are blind, hate in order to love, die in order to live, refuse education in order to learn, and murder in order to create" (p. 19).

Elizabeth A. Schultz is associate professor of English at the University of Kansas and associate editor of American Studies. In addition to articles on black American literature and music, Professor Scbultz bas published several poems, short stories, and reviews, and she is also interested in Japanese culture.
}

College English

Vol. 41, No. $2 \bullet$ October 1979

Copyright $(\mathbb{C} 1979$ by the National Council of Teachers of English. All rights reserved. 
ten by white Americans in the doctrines of Puritanism, in the institutions of democracy as they evolved in America in the eighteenth and nineteenth centuries, and in the opening of the frontier. ${ }^{2}$ Houston Baker, Jr., however, examining the black experience from a historical perspective, argues that black Americans were not as affected by these causes as white Americans, and Baker suggests that as a result the character of the black community is different from that suggested by Rosenblatt:

black American culture was never characterized by the individualistic ethos of white American culture; brought to America in shackles and placed in a society where all technology and wealth were in the hands of whites, black Americans had little opportunity to participate in American dreams of rugged individualism or fantasies of individual advancement. Black American culture is characterized by a collectivistic ethos. ${ }^{3}$

The recent surge of black novels which demonstrate the harmonious relationship between individual and community and Baker's sense of black American culture as "a collectivistic ethos" must be seen as related to the current re-examination of that culture by historians, sociologists, folklorists, and black aestheticians. ${ }^{4}$ Stanley M. Elkins, discussing the views of slavery proposed in several studies published within the last five years, points out that writers no longer emphasize the "damage" to individuals or families done by the system of slavery, but argue instead that the resistance to slavery has led to the creation of a black culture and community. ${ }^{5}$ Similarly, theoreticians of the black aesthetic increasingly have expanded their focus to include not just the dehumanizing emotional and physical effects of racism but also the growth of a common tradition within the black community. Hoyt W. Fuller, for example, identifies an attitude of "exhortation and celebration" as characteristic of recent black writing:

The new black writers have decided that their destiny is not at the mercy of the white man, that they live in a world with options. This does not mean that they have ceased to protest the indignities they still experience. . . . [But it is] Positive protest that creates as it eliminates: it deals with the opposition's ugliness by concentrating on its own beauty. ${ }^{6}$

Thus, although Rosenblatt's view of the alienating conditions of Afro-American life may be understood by contemporary black writers, a life of isolation and negation is perceived by many of them as neither the predominant pattern of experience nor as irrevocable. The effects of slavery and racism-"the cruelty, contempt, and, not least, uncertainty" which Elkins fears recent historians have ignored in stressing the miracle of the creation of culture (p. 54)-are fully recognized in the fiction of con-

\footnotetext{
${ }^{2}$ The American Novel and Its Tradition (Garden City, N.Y.: Doubleday, 1957), p. 11.

${ }^{3}$ Long Black Song: Essays in Black American Literature and Culture (Charlottesville: University Press of Virginia, 1972), p. 16.

${ }^{4}$ Some might argue that the black aestheticians and such groups as Chicago's Organization of Black American Culture have sought to prescribe such a theme to contemporary black fiction writers. However, although the predominance of this theme seems a recent phenomenon, it is of no recent date. Such early novels as Sutton Griggs' Imperium in Imperio (1899), W. E. B. Du Bois' The Quest for the Silver Fleece (1911), Arna Bontemps' Black Thunder (1936), Owen Dodson's Boy at the Window (1951), Gwendolyn Brooks' Maud Martba (1953), John O. Killens' Youngblood (1954), and Frank London Brown's Trumbull Park (1959) indicate that black writers consistently have concerned themselves with celebrating a shared historical, emotional, and aesthetic tradition.

5"The Slavery Debate," Commentary (December, 1975), pp. 40-54.

6"The New Black Literature: Protest or Affirmation," in The Black Aesthetic, ed. Addison Gayle, Jr. (Garden City, N.Y.: Anchor Books, 1972), p. 346.
} 
temporary black writers. But their vision is directed toward that miracle, toward their sense of a shared historical, emotional, and aesthetic tradition, toward their own community with its possibilities for pride and laughter and love.

The strength of the community, as it generates and perpetuates its own ethos, is particularly revealed in contemporary black fiction of two types: the initiation novel and the salvation novel. In the former, the young protagonist discovers his identity by finding heroes, traditions, and emotional support within the Afro-American community. In the latter, the protagonist or, indeed, the community as a whole is not concerned with the discovery of identity, but rather with the salvation of the communal identity in the face of continuing oppression. In both categories the writers' exuberant endorsement of their culture is reinforced by the prevalence of the images and rhythms of Afro-American speech and music in their novels.

In the contemporary black initiation novel the young protagonist is able to define himself or herself within the context of the community, not outside it, or in reaction to it. Albert Murray's Train Wbistle Guitar (New York: McGraw-Hill, 1974), for example, is essentially concerned with a boy's search for self and a father-figure in a small, tightly-knit Alabama black community. Murray shows us that "There was a child went forth every day,/ And the first object he look'd upon, that object he became": Scooter goes forth, listening, seeing, and remembering the sights and sounds, the people and tales he meets and hears in his community. He searches frontiers close to home: "Being also explorers and also discoverers and also wagon train scouts as well as sea pirates and cowboys among all the other things you had to be besides also being a schoolboy" (p. 37). Yet, above all, he yearns to be like the hobo, Luzana Cholly, who, in being always associated in the boy's mind with the sound and motion of the train heading for parts unknown, seeks more distant frontiers. Early in the novel, however, when Scooter had tried to snag a train to follow Luzana on his travels, the hobo had stopped him, insisting that he "Make old Luze proud of you . . . Make old Luze glad to take bis bat off to you some of these days. You going farther than old Luze ever dreamed of" (p. 30). And at the conclusion of the novel Scooter has gone beyond Luzana. He assimilates the vitality and soul of all his childhood heroes literally when he learns that his father may be Gator Gus or Stagolee Dupas or even Luzana and when he writes the novel, recreating these heroes through his lyrical reminiscences of his childhood. In assimilating them, Murray implies, Scooter attains his identity. ${ }^{7}$ His search has begun and ended where it started-in the "collective ethos" of the black community.

In the black novels of initiation of the last decade, the young protagonists encounter a series of social trials. The most difficult of these rites-of-passage is the one which forces the young protagonists to acknowledge they are black, and consequently, to recognize that, like those they love, like those they know to be good and beautiful, they also are bound to be betrayed by forces outside their comprehension. The events which confront the heroes and heroines in their coming-of-

\footnotetext{
${ }^{7}$ Given the fact that Murray's South to a Very Old Place (New York: McGraw-Hill, 1971), a personal journal of a trip he made back through the south he knew as a boy, invokes many of the same names and enthusiasms as does Train Whistle Guitar, it is tempting to speculate on the autobiographical implications of his novel. Murray, the man with the memories, would seem to consider himself the descendant of a boy like Scooter.
} 
age are bewildering; nothing is what it should be. ${ }^{8}$ Thus MC of Al Young's Snakes (1970) finds his friend Champ one night battered physically by unknown thugs and emotionally defeated by drugs; Wilford Robinson of Ronald Fair's Hog Butcher (1966) witnesses the senseless police-shooting of Cornbread Hamilton, the idol of all the neighborhood boys; Francie of Louise Meriwether's Daddy Was a Number Runner (1970) is powerless to prevent her father's demoralization through his loss of any dignified labor, her mother's degradation through her application to the city welfare office, and her brother's false arrest for murder; Tish Rivers of James Baldwin's If Beale Street Could Talk (1974) lives with the terror that her lover and the father of the child she is bearing, imprisoned on a trumped-up rape charge, will not receive justice; even Scooter of Train Whistle Guitar watches while the great white law breaks up the beautiful honky-tonk piano music of Stagolee Dupas. In almost all cases, the young protagonists are shocked by an act of violent injustice into an awareness of their racial identity, into the knowledge of white oppression and the strength of the black community.

In addition to their sense of confusion and insecurity in facing the brutality and duplicity caused by white racism, the young people of these initiation novels must face the confusion and insecurity of their ripening sexuality. Young black men have learned in the novels since the days of Wright's heroes-Bigger, Fishbelly Tucker in The Long Dream (1958), and Big Boy in "Big Boy Leaves Home" (1938)-that an involvement of any kind with a white woman may be lethal. MC and Scooter never consider the dangerous temptations of white flesh, being readily initiated into the joys of sex by generous black women, and Chuck Othello Chaney of John O. Killens' 'Sippi (1967) casually throws aside a white woman's attentions for his black sweetheart. For young black girls, however, it is more difficult. Harlem girls Francie and Tish are constantly subject to the advances of white men. Although they respond with fear and disgust, their emotional stability, which is severely taxed by such sexual harassments, remains steady, and their hostility is directed against white men, not sexuality itself. Both boys and girls, however, are exposed to the potentiality of violence between men and women. Thus Scooter remembers Bea Ella Thornhill cutting up Beau Beau Weaver for betraying her with another woman, and Francie knows that China Doll, the older sister of her best friend, was beaten up regularly and brutally by her pimp until she was finally driven to stab him to death.

Given the nature of racial oppression in America, such trials are in addition to the usual trials of adolescence. Black boys and girls in contemporary black initiation novels, however, confront them and survive to become vigorous members of the black community. In general, they survive because they have absorbed the traditions of "grit, shit, and mother wit" which have been passed on to them from older members of the community. Sexual turmoil is alleviated for boys by their finding with apparent ease an older black woman eager to initiate them into the pleasures of sex; it is eased for girls by their mothers' ready explanation of menstruation as a

\footnotetext{
${ }^{8}$ Rosenblatt observes that the process by which "the black man in a white society . . . taught to conceive of himself physically as an image of the negative, begins to see his whole life as a series of oppositions ... particularly [characterizes] novels that deal with growing up" (p. 18). More in line with the representation of the young person's search for identity in contemporary black novels, however, is Erik H. Erickson's comment that black authors give us "the creative individual [who] must accept the negative identity as the very base line of recovery" (Ident ity: Youtb and Crisis [New York: Norton, 1968], p. 25).
} 
natural phenomenon and by visits with the friendly neighborhood whores, although sex itself may remain an unknown.

Although not all of them have the support of the entire community in their trials, the young black protagonists do have the support of their families, of at least one parent or a grandparent, and almost inevitably of a friend with whom the mysteries of the initiation into community life may be shared. Although the adult community at large may at times seem treacherous, the adult upon whom the child is immediately dependent is uncompromising in his or her love. This adult is consistently a model for behavior and the source of knowledge and pride, but especially during times of racial and sexual crises, he or she sustains the child with love and wisdom. For Bigger Thomas and the narrator of Invisible Man, there were no such models who could help clarify confusion and foster a sense of personal security and worth. In Kunta Kinte's Gambian community in Alex Haley's Roots (1976), a work perhaps best understood as a novel rather than an historical document, however, each adult assists the growing boy in his rites-of-passage. Later Kunta himself, still remembering and respecting his elders, acts in accordance with their teachings despite the anguish of his dislocation from Africa. He becomes the model for his daughter and, as Haley strives to make us believe, for all of his descendants in the Afro-American community.

Thus as the individual in these novels of initiation learns within the framework of the black community, personal values become synonymous with communal values. Among the values which the young black person must acquire is the particularly American value of self-reliance. Self-reliance, however, is not needed for lonely survival in a strange natural world; it is necessary for survival in a hostile social world. In order for the individual black American to be self-reliant, he or she must paradoxically rely on the community. Consequently, the desire to survive and the quest for freedom are contingent upon the individual's relationship with others. In both Ronald Fair's novels, Hog Butcher (1966) and We Can't Breathe (1972), for example, coming-of-age in Chicago's black ghetto for the young protagonists necessitates their coming to appreciate their communities. When the close security of his boyhood gang disappears in drugs and death in We Can't Breathe (New York: Harper and Row, 1972), Ernie Johnson becomes conscious of himself as an isolated being and of the arbitrary and brutal nature of external forces; however, he can fall back on a sense of self-respect, a respect for the steady struggle of his parents, and a respect for all black people through his recitation of Sterling Brown's poem, "Strong Men"-a secular incantation of faith. He realizes how dependent he is upon his people for his very independence: "Survival to me now was getting out of the white neighborhood and back into my own so that I could run in peace, so that I could holler, so that I could jump up and down and yell" (p. 179). Brer Rabbit rejoices in the Briar Patch. The initiation rites of Milkman Dead in Toni Morrison's Song of Solomon (1977) do not occur until his thirties, but as he is stripped of his vanity and his materialistic values and faces the emptiness of his life alone and confused, he comes to understand not only the meaning of his singular name, but also the meaning of his family's song and of his kinship with them.

Thus the recent black writers of the initiation novel succeed in creating a fine balance between the conventionally opposed forces in American fiction: the freedom of the individual and the love of family or community. Indeed, as young pro- 
tagonists come to recognize the fact of their membership in their community, the novels forcefully demonstrate the possibilities for unity, harmony, and order. The conventional patterns of "alienation, contradiction, and disorder," that Richard Chase suggests as the dominant characteristics of American fiction (p. 2), are not reinforced in those contemporary black novels which focus on personal selfdiscovery.

But if conflict between opposing forces is not central to the black initiation novel, it is to the contemporary black salvation novel. The conflict which exists in these novels is between the individual, supported by the community, and various forces of annihilation. Salvation requires the obliteration of these forces. These forces may be readily and specifically identified as the manifestations of a corrupt, racist, bureaucratic, materialistic, and imperialistic society, but more generally they are forces which stand in opposition to life. The conflict in the salvation novel can be said to be between death and life, between the possibility of physical and psychological annihilation, on the one hand, and the possibility of freedom, creativity, and love, on the other. Salvation in these novels is possible when black people affirm that pride and laughter and love-the sources of life, the means of survival-are generated in their own community, and when they find that an apocalyptic revolution, whether military or spiritual, guarantees the perpetuation of these life sources.

Unlike the black initiation novels, the protagonist in this second major category of contemporary black American fiction does not have to discover the inequities of white racism; he already knows them. Julian Mayfield suggests that the quest for identity has no relevance for black American fiction: "If a black man doesn't know who he is, he need only wait upon the first white person he meets who will indicate it to him. In a war situation such as we find ourselves in, it isn't good to be confused about your indentity." With racism a given in their lives, the characters in these novels are committed not to self-discovery, but either to an affirmation of their identity within the Afro-American community or to a transformation of the oppressive status quo by apocalyptic means from within the community.

In George Cain's Blueschild Baby (1970) and Sarah Wright's This Child's Gonna Live (1969), the odds against the protagonist's even surviving the forces of annihilation would seem overwhelming, Cain's novel being a story of a young man's attempt to free himself from the bondage of heroin, and Wright's the story of a young woman's attempt to free herself, her children, and her husband from the bondage of rural poverty. In both cases, an oppressive condition, caused by the pervasive power of whites, creates a physical and mental slavery; yet each of the protagonists is saved from such slavery by the fact that they love and are loved. ${ }^{10}$ Theirs is a personal salvation, however; they survive, but they make no attempt to change the American racist system. In other salvation novels, the characters and the community work within the process of historical change. In Ernest Gaines' The Autobiograpby of Miss Jane Pittman (New York: Dial, 1971) and in Margaret Walker's Jubilee (1966), the protagonists survive the upheavals in American history which should have brought

\footnotetext{
${ }^{9}$ In Interviews with Black Writers, ed. John O'Brien (New York: Liveright, 1973), p. 149.

${ }^{10}$ As with several other male characters in recent black fiction-Cecil Braithwaite in John Wideman's Hurry Home (1970), Eugene Browning in John A. Williams' Sons of Darkness, Sons of Light (1969)-the proof of the protagonist's salvation in Blueschild Baby is explicit in his expression of love for a black woman.
} 
change in the de facto status of Afro-Americans as well as in their de jure status; when no change is apparent, both actively work to attain freedom for themselves and for those they love. ${ }^{11}$

At the age of eleven, Jane Pittman haggled with her first white overlord for a woman's wages, and at the age of 100 odd, she defies her last white overlord to join the Freedom Marchers. In Gaines' novel Jane becomes a repository of the history and culture of her people, for her actions and her convictions, even when they are personalized, are done or expressed in harmony with the people with whom she works in the fields or lives in the quarters. In the "Introduction" Gaines' fictional editor makes Jane's voice the collective voice of her people by thanking "all the wonderful people who were at Miss Jane's house through those long months of interviewing her, because this is not only Miss Jane's autobiography, it is theirs as well . . Miss Jane's story is all of their stories, and their stories are Miss Jane's" (p. $\mathrm{x})$. In conjunction with historical forces, the people as a community, motivated by Jane, join her on the march to change their joint destinies. Although individual saviors may come, Gaines suggests, finally the whole community, represented by Jane, must and will act in time to save itself.

Other contemporary Afro-American salvation novels focus upon communal commitment to an apocalyptic purgation of oppressive forces. While the characters of Blueschild Baby, This Child's Gonna Live, Jubilee, and The Autobiography of Miss Jane Pittman have the means to co-exist with a system of oppression during a particular moment in historical time, while they may dream better dreams for the future, they do not envision apocalyptic change. Baker points out that an "apocalypse theme" pervades black American literature, as has always been clearly manifest in the spirituals with their "promised joy of salvation and escape" and the "sense of black "fused strength"' (p. 32). The powerful voices of revolutionaries David Walker, Frederick Douglass, and Malcolm X, urging the abolition of slavery and the uplifting of black consciousness, as well as the voices of black preachers, lie behind these apocalyptic novels which demand salvation through radical change, militant or spiritual.

In those salvation novels insisting on military revolution, the apocalypse occurs very definitely in the physical world -armed force is pitted against armed force, fire against fire-and the conflict seems a simplistic allegory with clear moralistic overtones. Black, equalling good, is pitted against white, equalling bad. The individual protagonist in these salvation novels of the physical apocalypse, who is invariably the people's savior, may have some personalizing features-his stature, intelligence, love of a particular woman-but he is a character whose personal attributes are diminished in relation to his concern for his people; he thinks of them, in turn, not concretely as his family, his friends in the quarters, but abstractly. He conceives of an Afro-American nation, often joined with African nations; his revolution must affect all black peoples. Occasionally acting alone, he usually acts in concert with a group. His and their tools are those which the protagonists of the contemporary black initiation novel are also skilled in using, "grit, shit, and mother wit"; but he is

\footnotetext{
${ }^{11}$ In his earlier novels, Catharine Carmier (1964) and Of Love and Dust (1967), however, Gaines writes of the tragedy derivative of the intransigence of racism. Both the continuation of the old order and the attempts to change it insure only waste-the loss of love and energy. Gaines' most recent novel, In My Fatber's House (1978), describes a husband and father's struggle to redeem himself for betraying his family, while, ironically, he became involved in saving his community.
} 
also skilled in using arms and armaments, depending above all upon fire, not "the next time," but now.

In both Ronald Fair's Many Thousand Gone (1965) and William Melvin Kelley's A Different Drummer (1962) there is apocalypse; a savior is found, a fire is set, and a people freed. Both novels are located in representative southern communities, and although whites, appearing for the most part en masse as cowardly aggressors, are determined to keep their power by rape and lynching, deceit and brutality, the blacks are united against this force. As in Miss Jane Pittman, in these novels the community itself finally becomes the hero, becomes its own savior. In neither Drummer nor Many Thousand is there a plan of action for life following the flight and the fire with which they conclude; there is only the formulated hope of new beginnings, the flight leading the people out of Pharaoh's Land and the fire being one not only of destruction, but also of purification. The apocalypse is in medias res at the end of Sam Greenlee's The Spook Who Sat by the Door (New York: Bantam, 1969), and the protagonist, Freeman, as he listens to the firing of explosives over Chicago in counterpoint to Lady Day's singing "God Bless the Child," thinks that he has got his own like the song says: "I dig being black and the only thing I don't dig about being black is white folks messing with me" (p. 243). Like Bigger Thomas, who burns Mary Dalton's corpse, and like Lawrence of Nolan Davis' Six Black Horses (1971), who burns his sumptuous funeral emporium, the characters of these novels find salvation through an apocalypse of violence. They do indeed "murder to create," as Rosenblatt sees is typical of the behavior of characters in black fiction. Yet Bigger remains an alienated being with a private vision, whereas the communities in A Different Drummer, Many Thousand Gone, and The Spook Who Sat by the Door act in unison with their use of fire to gain a communal sense of new beginnings. Even the isolated protagonist of Invisible Man comes closest to being one with his fellow Afro-Americans when he joins a group of ordinary black citizens who are taking advantage of a Harlem riot to set fire to their rotting tenements.

In John A. Williams' recent novels, Sons of Darkness, Sons of Light (1969) and Captain Blackman (1972), the protagonists do not have to protest their identity or concentrate all their energies on survival alone as was the case with the protagonist of Williams' better-known The Man Who Cried I Am (1968). As Mayfield has commented, a black man will know himself by the side he naturally takes in "a war situation such as we find ourselves in"; so both Eugene Browning and Abraham Blackman know themselves, their allegorical names identifying them with their people, and have taken sides in the war. Both are also the masterminds for plots which allow blacks ultimately to take control of the white world. "King Alfred," the world-wide conspiracy to gain control over black people in The Man Who Cried I Am, has fallen into the hands of its potential victims in Sons of Darkness, Sons of Light and Captain Blackman, and they use it triumphantly against their oppressors.

Finally, within the category of the salvation novel are those novels in which the conflict between the forces of life and death is resolved by a spiritual apocalypse. No longer dependent on external events, programs, or individuals, black people realize that they can be their own gods, their own saviors, in the realm of their own minds. The fires of change occur in the consciousness of the individual or the culture rather than in actual historical time or through futuristic revolution. As John Wideman has said of his novel, The Lynchers (1973): 
it doesn't make any difference whether the conspirators pull their plot off or not, it doesn't make any difference whether we have an Armageddon in America or not; what does matter is what certain social realities have pushed these characters to, what attitudes are taken by both blacks and whites. In fact, a subterranean apocalypse does come to pass because people are changed more by their imagination than they are by external events. ${ }^{12}$

The conflict in the novels of the spiritual apocalypse may have a racial dimension, but it is subordinate to the conflict between the spirit and all forces which would regulate and repress it. The conflict is thus between the superego and the libido, between totalitarianism, racism, institutionalized religion, materialism, on the one hand, and mystery, art, sex, laughter, on the other. Writers such as Ishmael Reed, John McCluskey, and Charles Johnson explore not only the political history of black America as do Gaines, Killens, Greenlee, and Williams, but the aesthetic and religious history as well; in addition, they draw on the mythologies of Africa, Asia, and Europe in an attempt to regenerate the myths which have nourished all cultures and to reveal the racial memory of humankind. The folk wisdom of Afro-American and African culture is represented as having the energy and the magic to transform and save us all, black and white alike. The novels of spiritual apocalypse hold out hope for the salvation of the American dream, of one human culture vitalized by many peoples.

Rather than being allegorical, these novels, therefore, seem mythical, transcending specific time and place. They have the quality of tales, as Reed in Yellow Back Radio Broke-Down (1969) addresses his readers as "Folks" and Johnson in Faith and the Good Tbing (1974) addresses them as "children" who might be gathered around to hear the story. Their style, as is also true of Train Wbistle Guitar, seems often an attempt to make a black music of words or, as Reed maintains was true in ancient African cultures, to let the words "have magical meanings . . . to be charms"; the artist who uses them is "fetish-maker,"13 "a necromancer," "a conjuror who works JuJu upon his oppressors; a witch-doctor who frees his fellow victims from the psychic attack launched by demons of the outer and inner world."14

Appearing in Reed's novels, Yellow Back Radio, Mumbo Jumbo (1972), and The Last Days of Louisiana Red (1974), is always a character who is the catalyst for change; associated with black folk tradition, he is very much like the necromancing, conjuring artist. Thus in Yellow Back Radio, there is Loop Garoo Kid, an exuberant mythic figure, who abides by no temporal or geographical limitations, no moralistic or institutional conventions. By using voodoo masses, jazz rhythms, and incantations, Loop conjures up the doom of the representative literary pedant, landowner, military man, and possibly the Pope himself.

Both Mumbo Jumbo and Louisiana Red center on the activities of PaPa LaBas, ageless Haitian and New Orleans voodoo doctor, scholar, detective, and proprietor of the Mumbo Jumbo Kathedral. In both novels, LaBas arrives on the scene to investigate a death which apparently signifies the advent of repression. He appears in Mumbo Jumbo to check up on the waning of the phenomenal Jes Grew and in Louisi-

\footnotetext{
${ }^{12}$ In Interviews with Black Writers, p. 218.

${ }^{13}$ In Interviews with Black Writers, p. 172.

${ }^{14}$ Ishmael Reed, "Introduction," 19 Necromancers from Now (Garden City, N.Y.: Doubleday, 1970), p. xvii.
} 
ana Red to check up on the death of the founder of Solid Gumbo Works. Jes Grew is "a psychic epidemic" which reached a climax during the jazz age and the Harlem Renaissance, leapfrogging from New Orleans to all parts of the country, sending people into states of "'uncontrollable frenzy,' . . . wriggling like fish, doing something called the 'Eagle Rock' and the 'Sassy Bump'."15 What LaBas' investigations uncover in Mumbo Jumbo is that time always restores Jes Grew, that its psychic vitality, which is manifested in the music, dancing, and poetry of black Americans, can only "spring back and prosper." His discovery in Louisiana Red is that the wisdom of the past-of "the old morality ... Voodoo, Confucianism, the ancient Egyptian inner duties"16 - will lead to the reformation of the spirit, that humankind will be able to depend on its inner spirit rather than on any external superstructure.

John McCluskey's hero, Mack, in Look What They Done to My Song (New York: Random House, 1974) has a sense of mission which remains consistent throughout the novel. Although in the hearts of an older generation he has become the embodiment of their hopes for "a natural-born leader," a savior of the race, as the communities in Miss Jane Pittman and Many Thousand had also embodied their hopes in a young Moses, ${ }^{17}$ Mack wants only to move people with his music: "To say I'm a leader in any other way is to place a heavy weight on me. Just say I'm the one who woke folks up to themselves one dawn, blowing wild and beautiful changes" (pp. 12-13). Like Reed's Jes Grew and Gumbo, he believes that music is "the spirithealer, the righteous juju" (p. 246), and with it Mack hopes to bring black folk in all walks of life to recognize their own particular glory and to unify them in that recognition. Together, with a young militant revolutionary and an Old Baptist preacher, his combo and the woman he loves, Mack begins not only a new church, but also a new movement "toward That Great Day When":

We ripples in the ripples in the ripples of holiness. We go on, substituting one church for another, one Messiah for another, one name of God for another. Church is, after all, any place the spirit roams free and burns us clean enough to touch, to love. (p. 242)

As they take to dancing in the aisles together, the congregation seems to generate their own apocalypse, with their love burning away their fears and angers and with the coming of a belief in their own capacity to create a new world.

With its insistence upon the community as the source of life, the contemporary Afro-American novel stands in antithesis to those novels by white and black Americans which have made the alienated American a fixture in our American literature curricula and in our imaginations. Implicit in Huck's rejection of "sivilization" and in the invisible man's disappearance underground is acknowledgement of the individual's right as an American to pursue his or her own sense of life, liberty, and happiness as well as acknowledgement of the failure of America as a society. The actions of these very American protagonists who, after the long struggle to attain an identity and a sense of values, must be alienated from society because they cannot

\footnotetext{
${ }^{15}$ Mumbo Jumbo (New York: Bantam, 1973), pp. 6-8.

${ }^{16}$ The Last Days of Louisiana Red (New York: Random House, 1974), p. 172.

${ }^{17}$ Arthur P. Davis comments in "Novels of the New Black Renaissance," CLA Journal, 28 (1978) that 'the 'Moses theme' . . . is the belief that God will send a 'leader' to suffering Negroes as He did to the enslaved Hebrews" (473).
} 
compromise what they have attained, demonstrate the incompatibility of freedom and love, the failure of the American dream. However, the contemporary AfroAmerican initiation novel, in its re-examination of the relationship between the young, self-reliant protagonist and his or her community, and the contemporary Afro-American novel of spiritual apocalypse, in its assertion of the possibilities of democracy as a "kosmos," challenge our persistent promulgation of the doom of the American dream. Yet the vision expressed in recent black fiction, as the novels of military apocalypse remind us, has been sharpened by the brutal facts of American racism as well as by the triumphant facts of the creation of an Afro-American culture. Thus the alienated protagonists of Afro-American literature-Kabnis, Bigger, the invisible man, and Pecola of The Bluest Eye-finally have more in common with their white counterparts-Natty, Huck, Gatsby, and Mira of The Women's Roomthan they do with other protagonists of the Afro-American novel, heroes and heroines like Scooter, Milkman, Miss Jane Pittman, and Mack, all of whom are at home in the rock of their community, of their "collective ethos."
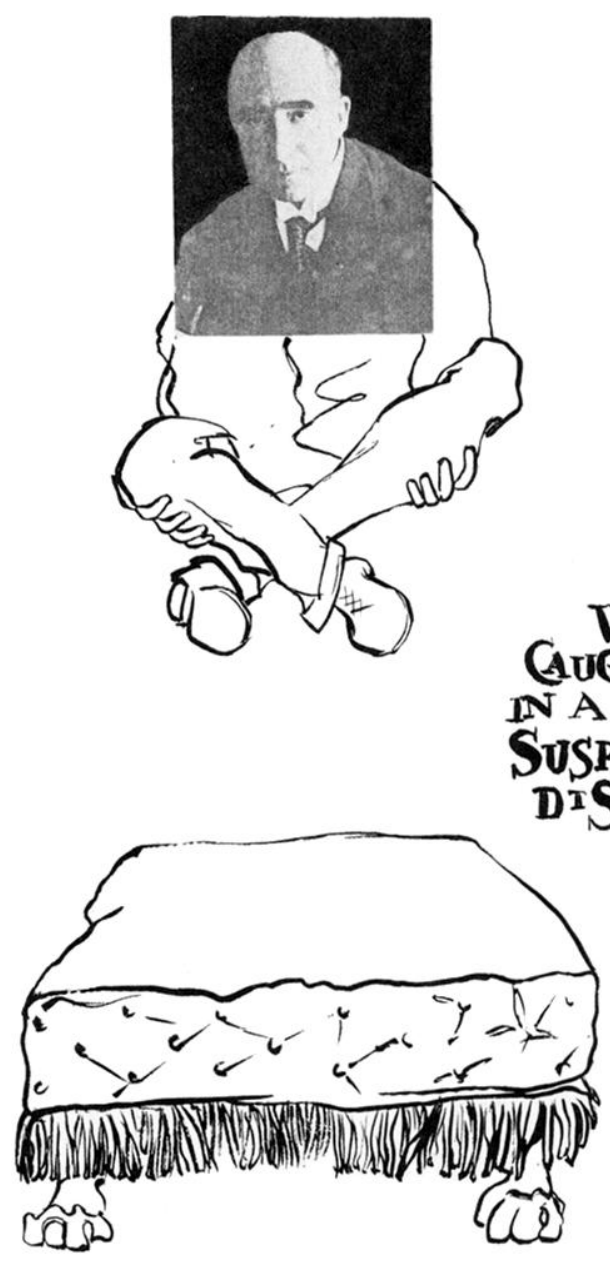

Sir ATIHUR IN A WILIING SUSPENSION OF DTSBELIEF. 